\title{
Acceleration of the Thrombin Inactivation of Single Chain Urokinase-type Plasminogen Activator (Pro-urokinase) by Thrombomodulin
}

Gerard A. W. de Munk, Eleonore Groeneveld, and Dingeman C. Rijken

Gaubius Institute TNO, Leiden, The Netherlands

\begin{abstract}
The in vitro effects of thrombomodulin on the inactivation of single chain urokinase-type plasminogen activator (scu-PA) by thrombin were investigated by incubating scu-PA with varying concentrations of human thrombin, in both the absence and presence of soluble rabbit thrombomodulin. $50 \%$ inactivation of scu-PA occurred in $45 \mathrm{~min}$ at $160 \mathrm{ng} / \mathrm{ml}$ thrombin in the absence of thrombomodulin and at $4.6 \mathrm{ng} / \mathrm{ml}$ thrombin in the presence of thrombomodulin. No difference was found in either the absence or the presence of thrombomodulin between the inactivation rates of high molecular weight scu-PA, and a low molecular weight scu-PA which lacked the growth factor and kringle domains. Enzyme kinetic experiments with varying concentrations of scu-PA showed that thrombomodulin decreased the $K_{\mathrm{m}}$ of thrombin for scu-PA from 7.8 to $0.43 \mu \mathrm{M}$ and increased the $\mathrm{k}_{\text {cat }}$ from 0.30 to $1.2 \mathrm{~s}^{-1}$, corresponding to a 70fold increase in the second-order rate constant $k_{\text {cat }} / K_{\mathrm{m}}$. SDSpolyacrylamide gel electrophoresis showed that scu-PA was cleaved into two chains upon inactivation by thrombin, and confirmed the acceleration effect of thrombomodulin on inactivation of scu-PA. Thrombomodulin thus not only has anticoagulant properties but is also antifibrinolytic. The acceleration may imply a new mechanism for the regulation of local plasminogen activator activity on the cell surface. (J. Clin. Invest. 1991. 88:1680-1684.) Key words: fibrinolysis • thrombolytic therapy • endothelial cells $\bullet$ protein $\mathrm{C} \bullet$ fetomodulin
\end{abstract}

\section{Introduction}

Single chain urokinase-type plasminogen activator (scu-PA), ${ }^{1}$ also called pro-urokinase, is the precursor of active two-chain urokinase-type plasminogen activator (tcu-PA), a serine protease that activates plasminogen to plasmin (for reviews, see 1-3). Although both forms of urokinase-type plasminogen ac-

This study was presented at the Tenth International Congress on Fibrinolysis, August 1990, Indianapolis, IN.

Address correspondence to Dr. Dingeman C. Rijken, Gaubius Laboratory IVVO-TNO, P.O. Box 430, 2300 AK Leiden, The Netherlands.

Received for publication 24 October 1990 and in revised form 2 August 1991.

1. Abbreviations used in this paper: HMW, high molecular weight; LMW, low molecular weight; S-2444, pyro-Gly-Glu-Arg-paranitroanilide; scu-PA, single chain u-PA; tcu-PA, two chain u-PA; t-PA, tissuetype plasminogen activator; $\mathrm{u}-\mathrm{PA}$, urokinase-type plasminogen activator.

J. Clin. Invest.

(c) The American Society for Clinical Investigation, Inc. $0021-9738 / 91 / 11 / 1680 / 05 \$ 2.00$

Volume 88, November 1991, 1680-1684 tivator (u-PA) are successfully applied for fibrinolytic therapy, it is not yet known whether u-PA plays an important role in endogenous fibrinolysis. On the other hand, scu-PA probably does play a role in cell migration, tissue destruction and tissue remodeling (for review, see 4). Both scu-PA and tcu-PA have $\sim 50,000 M_{\mathrm{r}}$; tcu-PA consists of two chains with $M_{\mathrm{r}} 20,000$ and 30,000 , held together by a disulfide bridge (5). In certain cell cultures a low molecular weight (LMW) form of scu-PA with $M_{\mathrm{r}} 32,000$ occurs $(6,7)$ that lacks the $\mathrm{NH}_{2}$-terminal part (the epidermal growth factor domain and the kringle domain) of the high molecular weight (HMW) form of scu-PA. No significant difference has yet been found between the thrombolytic properties of LMW scu-PA and HMW scu-PA $(8,9)$.

The single chain form of $\mathrm{u}-\mathrm{PA}$ can be converted to active tcu-PA by hydrolysis of the Lys 158 -Ile 159 peptide bond by plasmin (10), plasma kallikrein $(11,12)$, Factor XII (11), and trypsin (13). Thrombin hydrolyses scu-PA at the Arg 156-Phe 157 bond, leading to an inactive tcu-PA $(11,14,15)$, which is much less sensitive to activation with plasmin (16).

Thrombomodulin is a membrane protein of endothelial cells, which forms a 1:1 complex with thrombin (17) and stimulates the anticoagulant properties of thrombin by accelerating the activation of protein C (18), (for reviews, see 19-22).

The aims of this study were to investigate the effect of thrombomodulin on the inactivation of scu-PA by thrombin and to compare the inactivation by thrombin of HMW and LMW scu-PA. We found that thrombomodulin strongly accelerated the inactivation of both HMW and LMW scu-PA by thrombin.

\section{Methods}

Materials. Both HMW scu-PA and LMW scu-PA, purified from human embryonic kidney cell cultures (23), were donated by Dr J. Henkin, Abbott Laboratories (Abbott Park, IL). Rabbit lung thrombomodulin and goat anti-rabbit thrombomodulin IgG were purchased from American Diagnostica Inc. (Greenwich, CT). Hirudin was from Pentapharm (Basel, Switzerland). Goat non-immune IgG was isolated by two sodium sulfate precipitations (24). Human plasmin and chromogenic substrate Pyro-Glu-Gly-Arg-pNA (S-2444) were from Kabi AB (Stockholm, Sweden). Aprotinin was from Bayer AG (LeverkusenBayerwerk, Germany). Human thrombin (T 6759) and BSA (A 7030) were purchased from Sigma Chemical Co. (St. Louis, MO). A specific

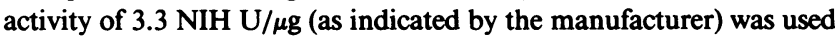
for the calculation of concentrations.

Assay of scu-PA. The activity of scu-PA was determined by measuring the latent amidolytic activity with S-2444 as follows: scu-PA was diluted with $20 \mathrm{mM}$ Tris/ $\mathrm{HCl}, \mathrm{pH} 7.5,100 \mathrm{mM} \mathrm{NaCl}, 3 \mathrm{mM} \mathrm{CaCl}{ }_{2}$, $0.1 \%$ Tween $80,0.1 \% \mathrm{BSA}, 0.2 \mathrm{U} / \mathrm{ml}$ hirudin (or more, depending on the amount of thrombin present in the solution) to a concentration of $60-1,000 \mathrm{ng} / \mathrm{ml}$ and plasmin was added (final concentration $0.1 \mathrm{CU} /$ $\mathrm{ml}$ ). After $20 \mathrm{~min}$ activation at $37^{\circ} \mathrm{C}$, the amidolytic activity of $75 \mu \mathrm{l}$ activated scu-PA solution was measured by adding $175 \mu \mathrm{l} 0.43 \mathrm{mM}$ $\mathrm{S}-2444$ in $50 \mathrm{mM}$ Tris $/ \mathrm{HCl}, 38 \mathrm{mM} \mathrm{NaCl}, 0.01 \%$ Tween 80 , and 20 $\mathrm{KIU} / \mathrm{ml}$ aprotinin, $\mathrm{pH} 8.8$. The increase of the optical density at 405 
nm was measured during incubation at $37^{\circ} \mathrm{C}$ by using a Titertek multiskan (Eflab Oy, Finland).

Complexation of thrombin with thrombomodulin. Various concentrations of thrombin up to $0.30 \mu \mathrm{g} / \mathrm{ml}(8.1 \mathrm{nM})$ were incubated with 1.0 $\mu \mathrm{g} / \mathrm{ml}$ thrombomodulin $(13.5 \mathrm{nM})$ for $5 \mathrm{~min}$ at $37^{\circ} \mathrm{C}$ immediately before each experiment. Functional activity of the thrombomodulin preparation was demonstrated by inhibition of the fibrinogen-clotting activity of thrombin by thrombomodulin, tested as described by Esmon et al. (17).

Inactivation of scu-PA. The principle of the assay for scu-PA inactivation has been described (15). During $45 \mathrm{~min}$ at $37^{\circ} \mathrm{C}, 240 \mathrm{ng} / \mathrm{ml}$ HMW or LMW scu-PA was incubated with $0-0.6 \mu \mathrm{g} / \mathrm{ml}$ thrombin or with $0-0.3 \mu \mathrm{g} / \mathrm{ml}$ thrombin after pre-incubation with $1 \mu \mathrm{g} / \mathrm{ml}$ thrombomodulin, in $20 \mathrm{mM}$ Tris/ $\mathrm{HCl}, \mathrm{pH} 7.5,100 \mathrm{mM} \mathrm{NaCl}, 3 \mathrm{mM} \mathrm{CaCl}_{2}$, $0.1 \% \mathrm{BSA}$, and $0.1 \%$ Tween 80 . The inactivation was stopped by diluting the mixture in cold hirudin-containing dilution buffer of the assay for scu-PA. In another experiment, varying concentrations of thrombomodulin $(0-1 \mu \mathrm{g} / \mathrm{ml})$ were pre-incubated with $15 \mathrm{ng} / \mathrm{ml}$ thrombin before $240 \mathrm{ng} / \mathrm{ml} \mathrm{HMW}$ scu-PA was added. After $45 \mathrm{~min}$ at $37^{\circ} \mathrm{C}$, the inactivation was stopped and remaining scu-PA was assayed.

Goat anti-rabbit thrombomodulin IgG $(40 \mu \mathrm{g} / \mathrm{ml})$ or goat non-immune IgG $(40 \mu \mathrm{g} / \mathrm{ml})$ was incubated at $37^{\circ} \mathrm{C}$ for $5 \mathrm{~min}$ with $50 \mathrm{ng} / \mathrm{ml}$ thrombomodulin. After thrombin was added $(15 \mathrm{ng} / \mathrm{ml}$ final concentration) and incubated again at $37^{\circ} \mathrm{C}$ for $5 \mathrm{~min}$, HMW scu-PA (240 $\mathrm{ng} / \mathrm{ml}$ final concentration) was added and incubated at $37^{\circ} \mathrm{C}$ for 45 min. Remaining scu-PA was measured.

The effect of $\mathrm{Ca}^{2+}$ on the inactivation of $240 \mathrm{ng} / \mathrm{ml} \mathrm{HMW} \mathrm{scu-PA}$ was studied by adding $0-0.60 \mu \mathrm{g} / \mathrm{ml}$ thrombin alone, or $0-0.12 \mu \mathrm{g} / \mathrm{ml}$ thrombin after incubation with $1 \mu \mathrm{g} / \mathrm{ml}$ thrombomodulin, both in the presence and in the absence of $3 \mathrm{mM} \mathrm{CaCl}_{2}$. After incubation at $37^{\circ} \mathrm{C}$ for $\mathbf{4 5}$ min, remaining scu-PA was assayed.

Kinetic experiments. Concentrations of HMW scu-PA ranging from 0.05 to $4 \mu \mathrm{M}$ were incubated with $4 \mathrm{nM}(150 \mathrm{ng} / \mathrm{ml})$ thrombin or $0.04 \mathrm{nM}(1.5 \mathrm{ng} / \mathrm{ml})$ thrombin after preincubation with $1 \mu \mathrm{g} / \mathrm{ml}$ thrombomodulin in $20 \mathrm{mM}$ Tris/ $\mathrm{HCl}, \mathrm{pH} 7.5,100 \mathrm{mM} \mathrm{NaCl}, 3 \mathrm{mM}$ $\mathrm{CaCl}_{2}, 0.1 \%$ Tween 80 , and $0.1 \% \mathrm{BSA}$ at $37^{\circ} \mathrm{C}$. At intervals of $0,15,30$, 45 and $60 \mathrm{~min}$, aliquots were taken and the reaction was stopped as described above. Remaining scu-PA was measured with S-2444 after activation with plasmin and the initial rates of scu-PA inactivation were determined from the linear parts of the time curves.

SDS-polyacrylamide gel electrophoresis. SDS-PAGE was performed according to the method of Laemmli (25), using a $12 \%$ polyacrylamide gel. Samples of $30 \mu$ l were diluted 1:1 in sample buffer containing 4\% (wt/vol) SDS, $20 \%$ (wt/vol) glycerol, $0.005 \%(\mathrm{wt} / \mathrm{vol})$ bromophenol blue and 4\% (wt/vol) 2-mercaptoethanol in $125 \mathrm{mM}$ Tris/ $\mathrm{HCl}, \mathrm{pH} 6.8$ and incubated for $5 \mathrm{~min}$ at $100^{\circ} \mathrm{C}$. A calibration kit with standard proteins was obtained from Pharmacia LKB Biotechnology (Uppsala, Sweden).

\section{Results}

Inactivation of $H M W$ and $L M W$ scu-PA. To study the effect of thrombomodulin on the inactivation of scu-PA by thrombin, $240 \mathrm{ng} / \mathrm{ml} \mathrm{HMW}$ and LMW scu-PA were incubated for $45 \mathrm{~min}$ at $37^{\circ} \mathrm{C}$ with varying amounts of thrombin, both in the absence and presence of $1 \mu \mathrm{g} / \mathrm{ml}$ thrombomodulin. Remaining scu-PA, not inactivated by thrombin, was activated with plasmin and quantified using S-2444. 50\% of scu-PA was inactivated by $160 \pm 41 \mathrm{ng} / \mathrm{ml}($ mean $\pm \mathrm{SD}, n=5)$ thrombin in the absence of thrombomodulin or by only $4.6 \pm 1.4(n=4) \mathrm{ng} / \mathrm{ml}$ thrombin in the presence of thrombomodulin (Fig. 1). No difference was found in the relative inactivation rate between LMW scu-PA and HMW scu-PA, either in the absence or in the presence of thrombomodulin.

Fig. 2 shows that remaining scu-PA gradually decreased at increasing thrombomodulin concentrations and a fixed throm-

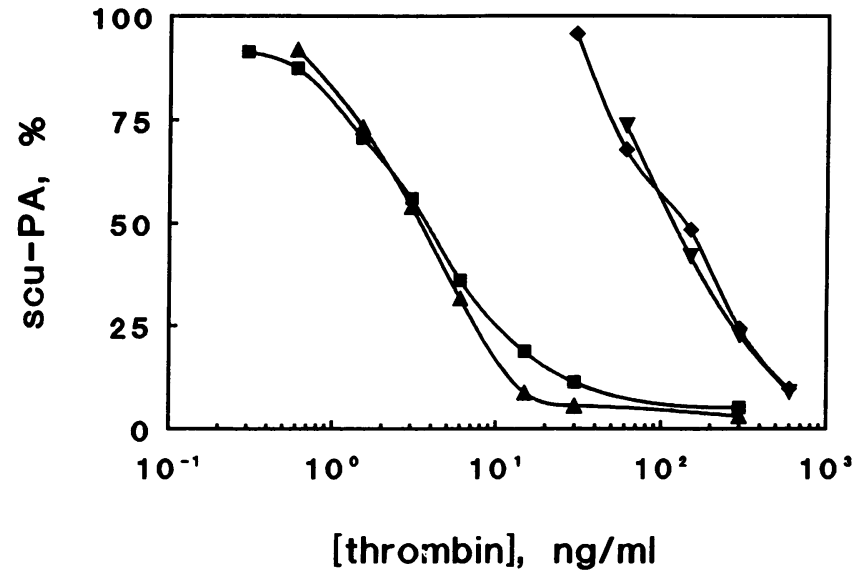

Figure 1. Effect of thrombomodulin on the inactivation of HMW scu-PA ( $\bullet$ and $\bullet$ ) and LMW scu-PA ( $\triangle$ and $\nabla)$ by thrombin. The percentages of scu-PA remaining after incubation for $45 \mathrm{~min}$ at $37^{\circ} \mathrm{C}$ with varying concentrations of thrombin in the absence $(\diamond, \nabla)$ or in the presence of $1 \mu \mathrm{g} / \mathrm{ml}$ thrombomodulin $(\boldsymbol{\Delta}, \Delta)$ were quantified with $\mathrm{S}-2444$ after activation with plasmin. The $100 \%$ values were not affected by either the absence or presence of thrombomodulin.

bin concentration of $15 \mathrm{ng} / \mathrm{ml}$. To calculate the $K_{\mathrm{d}}$ for the thrombin-thrombomodulin complex from these data, the percentages of remaining scu-PA were converted into concentrations of the thrombin-thrombomodulin complex, by reference to the standard curve prepared with thrombin in the presence of $1 \mu \mathrm{g} / \mathrm{ml}$ thrombomodulin (Fig. 1) and by assuming that all thrombin had formed a 1:1 complex at $1 \mu \mathrm{g} / \mathrm{ml}$ thrombomodulin. The concentrations of free and bound thrombomodulin were calculated and plotted double reciprocally (Fig. 2, inset), resulting in an apparent $K_{\mathrm{d}}$ of $0.57 \mathrm{nM}$ for the thrombinthrombomodulin complex.

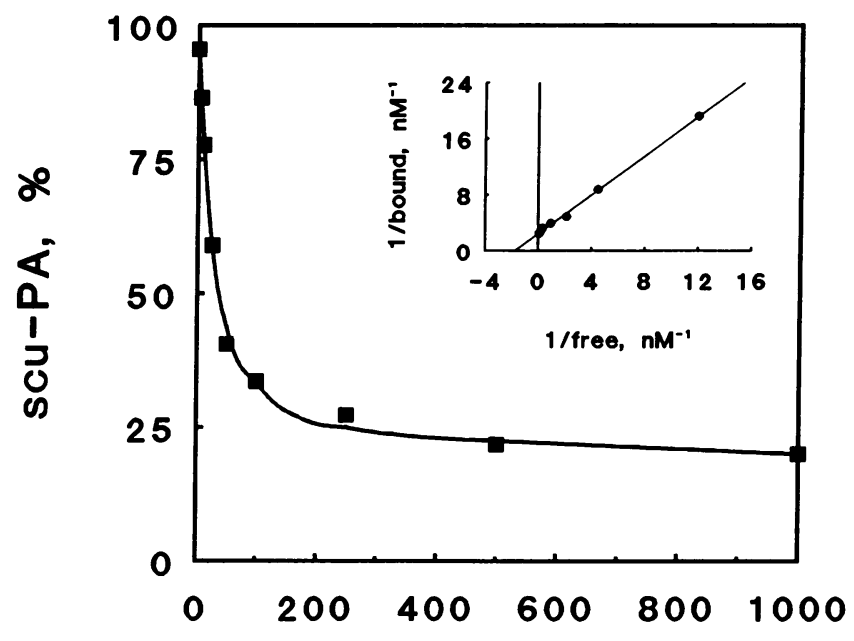

\section{[thrombomodulin], $\mathrm{ng} / \mathrm{ml}$}

Figure 2. Effect of varying concentrations of thrombomodulin on the inactivation of HMW scu-PA by thrombin. Thrombin $(15 \mathrm{ng} / \mathrm{ml})$ was preincubated with $0-1 \mu \mathrm{g} / \mathrm{ml}$ thrombomodulin for $5 \mathrm{~min}$ at $37^{\circ} \mathrm{C}$ and then incubated with $240 \mathrm{ng} / \mathrm{ml} \mathrm{HMW}$ scu-PA for $45 \mathrm{~min}$ at $37^{\circ} \mathrm{C}$. The amounts of free and bound thrombomodulin were calculated from the activities of the thrombin-thrombomodulin mixtures (see text) and plotted double reciprocally to determine the $K_{d}$ (inset). 
The neutralizing effect of goat antibodies against thrombomodulin was studied in Fig. 3. Approximately 4\% scu-PA was inactivated by $15 \mathrm{ng} / \mathrm{ml}$ thrombin alone, whereas $56 \%$ was inactivated by the same concentration thrombin complexed with $50 \mathrm{ng} / \mathrm{ml}$ thrombomodulin. The antibodies almost completely quenched the accelerating effect of thrombomodulin on the inactivation of HMW scu-PA, whereas goat non-immune IgG had only a minor effect.

$S D S-P A G E$ of inactivated $H M W$ and LMW SCu-PA. HMW and LMW scu-PA were incubated with a low concentration of thrombin $(75 \mathrm{ng} / \mathrm{ml})$, both with and without $1 \mu \mathrm{g} / \mathrm{ml}$ thrombomodulin, or with a high concentration of thrombin $(1.2 \mu \mathrm{g} / \mathrm{ml})$, and subjected to SDS-PAGE (Fig. 4). The low concentration of thrombin partially cleaved HMW scu-PA into two subunits: one of $M_{\mathrm{r}} 32,000$ and one of $M_{\mathrm{r}} 20,000$ or 22,000 (lane 3). In contrast, the thrombin-thrombomodulin complex completely cleaved HMW scu-PA (lane 4), as did the high concentration of thrombin (lane 5). Comparison of the extent of cleavage in lanes 3 and 4 clearly shows the accelerating effect of thrombomodulin. As expected, inactivation of LMW scu-PA did not lead to a significant shift of the protein band, because a peptide of only 13 amino acids was supposed to be cut off.

Kinetics of the inactivation of $H M W$ scu-PA. Varying amounts of HMW scu-PA were incubated with thrombin or with thrombin after preincubation with excess thrombomodulin. Kinetic analysis shows that the inactivation rate of scu-PA by both thrombin and the thrombin-thrombomodulin complex obeyed Michaelis-Menten kinetics. Using LineweaverBurk plots (Fig. 5), the $K_{\mathrm{m}}$ and $\mathrm{k}_{\text {cat }}$ were determined to be 7.8 $\mu \mathrm{M}$ and $0.30 \mathrm{~s}^{-1}$, respectively, in the case of thrombin and 0.43 $\mu \mathrm{M}$ and $1.2 \mathrm{~s}^{-1}$, respectively, for the thrombin-thrombomodulin complex (Table I). The second-order rate constant $\left(\mathrm{k}_{\text {cat }} / K_{\mathrm{m}}\right)$ of thrombin increased from 0.039 to $2.7 \mu \mathrm{M}^{-1} \cdot \mathrm{s}^{-1}$ (70 times) by complex formation with thrombomodulin.

Effect of $\mathrm{Ca}^{2+}$ on the inactivation of $\mathrm{HMW}$ Scu-PA. In the presence of $\mathrm{Ca}^{2+}$ more thrombin was required to inactivate HMW scu-PA than in the absence of $\mathrm{Ca}^{2+}$. This was observed both in the presence ( 23 times more thrombin to achieve $50 \%$ inactivation) and in the absence ( 9 times more) of thrombomodulin (Fig. 6). An experiment with varying $\mathrm{Ca}^{2+}$ concentrations $(0-6 \mathrm{mM})$ revealed that under both conditions a plateau was reached at $3 \mathrm{mM} \mathrm{Ca}^{2+}$ (not shown).

\section{Discussion}

This study shows an accelerating effect of solubilized rabbit thrombomodulin on the inactivation of scu-PA by human

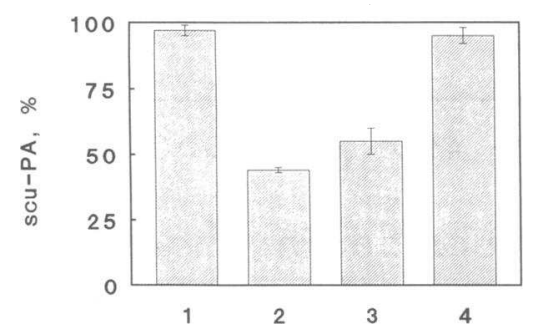

Figure 3. Quenching of the accelerating effect of thrombomodulin by specific antibodies. HMW scu-PA (240 ng/ $\mathrm{ml}$ ) was incubated for $45 \mathrm{~min}$ at $37^{\circ} \mathrm{C}$ with 15 $\mathrm{ng} / \mathrm{ml}$ thrombin (1), with $15 \mathrm{ng} / \mathrm{ml}$ thrombin preincubated in $50 \mathrm{ng} /$ $\mathrm{ml}$ thrombomodulin

(2), and with $15 \mathrm{ng} / \mathrm{ml}$ thrombin, $50 \mathrm{ng} / \mathrm{ml}$ thrombomodulin, and 40 $\mu \mathrm{g} / \mathrm{ml}$ goat non-immune IgG (3) or $40 \mu \mathrm{g} / \mathrm{ml}$ goat anti-thrombomodulin IgG (4). Standard deviations are presented as horizontal lines $(n=3)$.

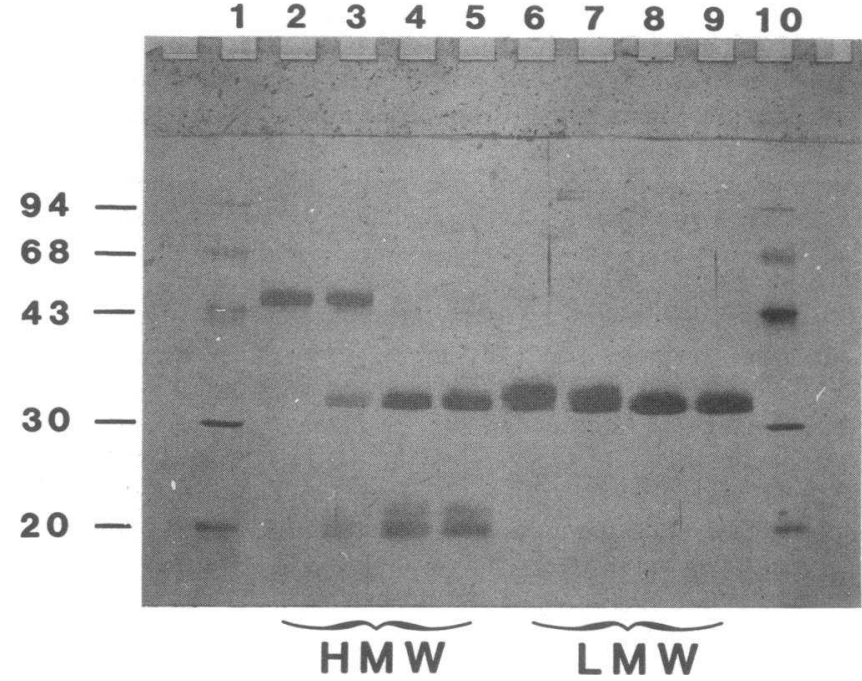

Figure 4. SDS-PAGE of inactivated HMW and LMW scu-PA. HMW and LMW scu-PA $(62.5 \mu \mathrm{g} / \mathrm{ml})$ were incubated for $45 \mathrm{~min}$ at $37^{\circ} \mathrm{C}$ in $20 \mathrm{mM}$ Tris/ $\mathrm{HCl}, 100 \mathrm{M} \mathrm{NaCl}, 3 \mathrm{mM} \mathrm{CaCl}_{2}$, and $0.1 \%$ Tween 80 , pH 7.5, as specified below. Lanes 1 and 10: Standard proteins with $M_{\mathrm{r}} 94,000,68,000,43,000,30,000,20,000$. Lane 2: HMW scu-PA; lane 3: HMW scu-PA after inactivation with thrombin $(75 \mathrm{ng} / \mathrm{ml})$; lane 4: HMW scu-PA after inactivation with thrombin $(75 \mathrm{ng} / \mathrm{ml})$ in the presence of $1.0 \mu \mathrm{g} / \mathrm{ml}$ thrombomodulin; lane 5: HMW scu-PA after inactivation with a high concentration of thrombin $(1.2 \mu \mathrm{g} / \mathrm{ml})$; lanes 6-9: as lanes 2-5 except that HMW scu-PA was replaced by LMW scu-PA. All samples were reduced with 2-mercaptoethanol. Protein bands were visualized with silver staining (26).

thrombin. This finding was supported by the following observations: (a) The effect of thrombomodulin was dose dependent and corresponded with an apparent $K_{d}$ for the thrombinthrombomodulin complex of $0.57 \mathrm{nM}$, which is very similar to previously reported values of 0.48 and $0.54 \mathrm{nM}(18,29)$. (b) Goat anti-rabbit thrombomodulin IgG inhibited the accelerating effect of thrombomodulin. (c) The action of thrombomodulin accompanied the conversion of scu-PA into a tcu-PA that was indistinguishable on SDS-PAGE from the tcu-PA formed by a high concentration of thrombin.

The inactivation of HMW scu-PA by the thrombin-thrombomodulin complex as well as by thrombin alone obeyed Michaelis-Menten kinetics. The $\mathrm{k}_{\text {cat }} / K_{\mathrm{m}}$ for thrombin alone was $0.039 \mu \mathrm{M}^{-1} \cdot \mathrm{s}^{-1}$ and increased 70 -fold to $2.7 \mu \mathrm{M}^{-1} \cdot \mathrm{s}^{-1}$ for the thrombin-thrombomodulin complex. It is difficult to establish whether the latter rate constant is high enough to be significant in vivo. However, the rate constant is of the same order of magnitude as that for the activation of scu-PA by plasmin (30, 31 ). In addition, the $\mathrm{k}_{\text {cat }} / K_{\mathrm{m}}$ for the activation of protein $\mathrm{C}$ by the thrombin-thrombomodulin complex in an assay system as used in this study is $0.81 \mu \mathrm{M}^{-1} \cdot \mathrm{s}^{-1}(27)$, which is also of the same order of magnitude (Table I). The activation rate of protein $\mathrm{C}$ by the complex further increases on cell surfaces and in the presence of phospholipids $(18,28)$. It still has to be determined whether the inactivation rate of scu-PA on cell surfaces is higher than in the solubilized system.

In the absence of endothelial cells, $\mathrm{Ca}^{2+}$ reduces the rate of protein $\mathrm{C}$ activation by thrombin, but stimulates the activation rate by the thrombin-thrombomodulin complex (32). The thrombin-thrombomodulin interaction is $\mathrm{Ca}^{2+}$ independent (17). In contrast to the diverging effects of $\mathrm{Ca}^{2+}$ on protein $\mathrm{C}$ 

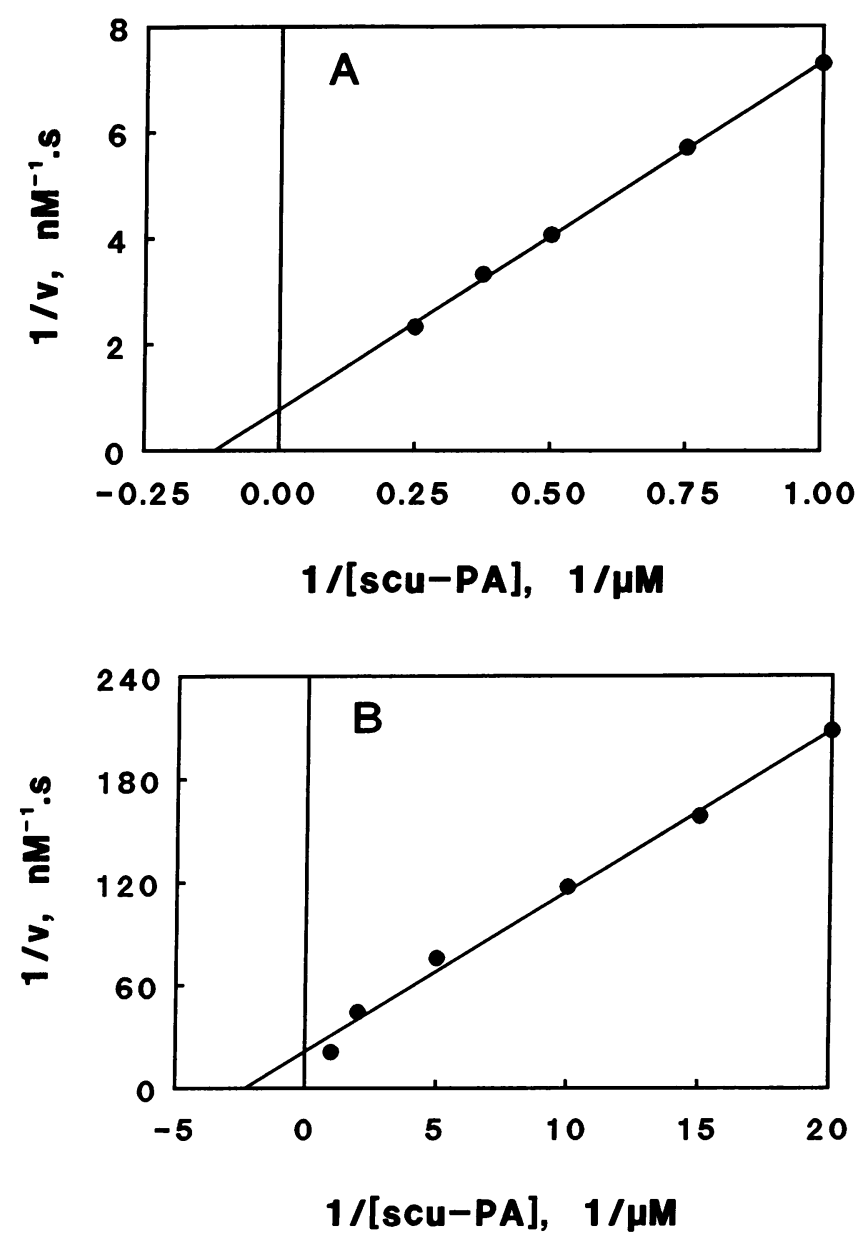

Figure 5. Lineweaver-Burk plots of the inactivation of HMW scu-PA. At varying concentrations of scu-PA, the inactivation rate of thrombin $(A)$ and thrombin in the presence of thrombomodulin $(B)$ was measured as described under Methods. The $k_{\text {cat }}$ and $K_{\mathrm{m}}$ values were determined by using the least squares method and are summarized in Table I.

activation, $\mathrm{Ca}^{2+}$ reduced the inactivation of scu-PA by both thrombin and thrombin-thrombomodulin complex. It is not yet clear whether the active site of thrombin is affected or whether the substrate scu-PA is changed by a hitherto unknown $\mathrm{Ca}^{2+}$-binding phenomenon.

The two molecular weight forms (HMW and LMW) of scu-

Table I. Kinetic Parameters of the Inactivation of HMW Scu-PA by Thrombin and Thrombin-Thrombomodulin Complex (Derived from Fig. 5) and a Comparison with Literature Data for the Activation of Protein C

\begin{tabular}{lllll}
\hline \multicolumn{1}{c}{ Enzyme } & Substrate & $K_{\mathrm{m}}$ & $\mathrm{k}_{\text {cat }}$ & $\mathrm{k}_{\text {cat }} / K_{\mathrm{m}}$ \\
\hline & & $\mu M$ & $s^{-1}$ & $\mu M^{-1} \cdot \mathrm{s}^{-1}$ \\
Thrombin & scu-PA & 7.8 & 0.30 & 0.039 \\
Thrombin-thrombomodulin & scu-PA & 0.43 & 1.2 & 2.7 \\
Thrombin* $^{*}$ & protein C & 60 & 0.02 & 0.00033 \\
Thrombin-thrombomodulin $^{\ddagger}$ & protein C & 7.6 & 6.2 & 0.81
\end{tabular}

* According to ref. $27 ;{ }^{\ddagger}$ according to ref. 28.

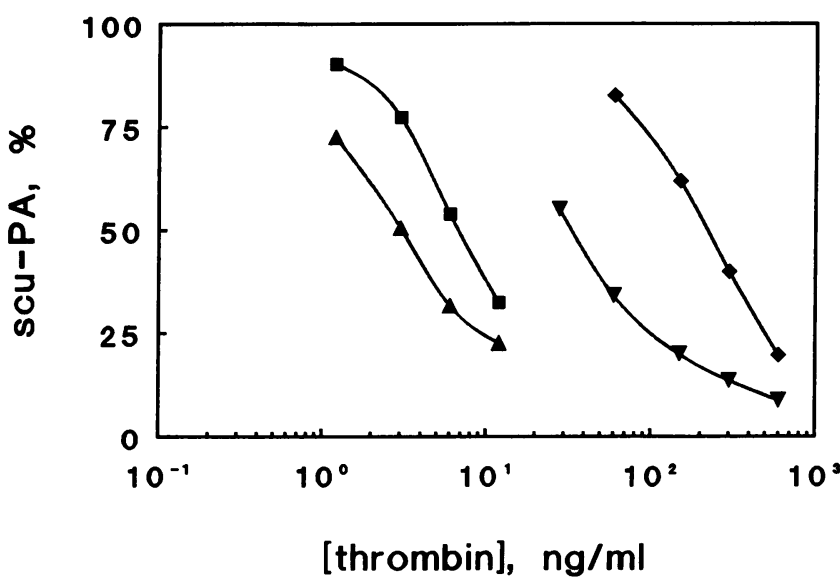

Figure 6. Effect of $\mathrm{Ca}^{2+}$ on the inactivation of HMW scu-PA. Remaining scu-PA was determined after inactivation by thrombin in the presence of $3 \mathrm{mM} \mathrm{Ca}^{2+}(\bullet)$ or absence of $\mathrm{Ca}^{2+}(\nabla)$ and by thrombin-thrombomodulin complex in the presence of $3 \mathrm{mM} \mathrm{Ca}^{2+}(\square)$ or absence of $\mathrm{Ca}^{2+}(\triangle)$. The concentration of scu-PA was $240 \mathrm{ng} / \mathrm{ml}$, the concentration of thrombomodulin was $1 \mu \mathrm{g} / \mathrm{ml}$. For experimental details see Methods.

PA were equally sensitive to inactivation by thrombin or the thrombin-thrombomodulin complex. LMW scu-PA, a potential thrombolytic agent, has, therefore, no advantage or disadvantage compared with HMW scu-PA in terms of sensitivity for inactivation in thrombolytic therapy.

The physiological importance of the acceleration of scu-PA inactivation by thrombomodulin may lie in the close regulation of local u-PA activity on surfaces of endothelial cells and other cells that express thrombomodulin. Through this mechanism thrombin and thrombomodulin may affect processes such as cell migration, tissue destruction and remodeling. In this respect, it is interesting to note that fetomodulin, a surface marker protein of fetal development, has recently been demonstrated to be identical to thrombomodulin (33). During embryonic development this marker is not only expressed in vasculatures but also in nonvascular tissues. Consequently, it has been suggested that thrombomodulin has another function, in addition to that of an anticoagulant (33). This study indicates such a function, implying the regulation of u-PA activity during embryonic development.

If scu-PA plays a role in endogenous fibrinolysis, thrombomodulin should be considered as a protein with antifibrinolytic properties in addition to its well-known anticoagulant properties. Both properties may be necessary, either simultaneously or successively, to regulate size and longevity of fibrin deposits. Inactivation of scu-PA by thrombomodulin-bound thrombin may also occur during thrombolytic therapy with scu-PA, the more so as thrombin seems to be formed in patients during thrombolysis (34). This would be an additional argument for administering thrombin inhibitors simultaneously with the thrombolytic agent scu-PA (35).

\section{Acknowledgments}

We thank Dr. J. Henkin and Dr. A. A. Sasahara, Abbott Laboratories, for generously providing HMW and LMW scu-PA.

This study was supported by the Netherlands Heart Foundation (grant 87.041 and Established Investigatorship of D. C. Rijken). 


\section{References}

1. Lijnen, H. R., D. C. Stump, and D. C. Collen. 1987. Single-chain urokinase-type plasminogen activator: mechanism of action and thrombolytic properties. Semin. Thromb. Haemostasis. 13:152-159.

2. Gurewich, V. 1988. Activation of fibrin-bound plasminogen by pro-urokinase and its complementariness with that by tissue plasminogen activator. Enzyme (Basel). 40:97-108.

3. De Munk, G. A. W., and D. C. Rijken. 1990. Fibrinolytic properties of single chain urokinase-type plasminogen activator (pro-urokinase). Fibrinolysis. 4:1-9.

4. Danø, K., J. Andreasen, J. Grøndahl-Hansen, P. Kristensen, L. S. Nielsen, and L. Skriver. 1985. Plasminogen activators, tissue degradation, and cancer. Adv. Cancer Res. 44:139-241.

5. Günzler, W. A., G. J. Steffens, F. Ötting, S.-M. A. Kim, E. Frankus, and L. Flohé. 1982. The primary structure of high molecular mass urokinase from human urine. The complete amino acid sequence of the A chain. Hoppe-Seyler's Z. Physiol. Chem. 363:1155-1165.

6. Wijngaards, G., D. C. Rijken, A. L. Van Wezel, E. Groeneveld, and C. A. M. Van der Velden. 1986. Characterization and fibrin-binding properties of different molecular forms of pro-urokinase from a monkey kidney cell culture. Thromb. Res. 42:749-760.

7. Stump, D. C., H. R. Lijnen, and D. Collen. 1986. Purification and characterization of a novel low molecular weight form of single-chain urokinase-type plasminogen activator. J. Biol. Chem. 261:17120-17126.

8. Rijken, D. C., D. J. Binnema, and P. Los. 1986. Specific fibrinolytic properties of different molecular forms of pro-urokinase from a monkey kidney cell culture. Thromb. Res. 42:761-768.

9. Stump, D. C., J. M. Stassen, E. Demarsin, and D. Collen. 1987. Comparative thrombolytic properties of single-chain forms of urokinase-type plasminogen activator. Blood. 69:592-596.

10. Nielson, L. S., J. G. Hansen, L. Skriver, E. L. Wilson, K. Kaltoft, J. Zeuthen, and K. Danø. 1982. Purification of zymogen to plasminogen activator from human glioblastoma cells by affinity chromatography with monoclonal antibody. Biochemistry. 21:6410-6415.

11. Ichinose, A., K. Fujikawa, and T. Suyama. 1986. The activation of pro-urokinase by plasma kallikrein and its inactivation by thrombin. J. Biol. Chem. 261:3486-3489.

12. Hauert, J., G. Nicoloso, W.-D. Schleuning, F. Bachmann, and M. Schapira. 1989. Plasminogen activators in dextran sulfate-activated euglobulin fractions. a molecular analysis of factor XII- and prekallikrein-dependent fibrinolysis. Blood. 73:994-999.

13. Bernik, M. B., and E. P. Oller. 1973. Increased plasminogen activator (urokinase) in tissue culture after fibrin deposition. J. Clin. Invest. 52:823-834.

14. Bernik, M. B., and E. P. Oller. 1977. Regulation of fibrinolysis through activation and inhibition of activation of a plasminogen proactivator (preurokinase). Thromb. Haemostasis. 38:136.

15. Gurewich, V., and R. Pannell. 1987. Inactivation of single-chain urokinase (pro-urokinase) by thrombin and thrombin-like enzymes: relevance of the findings to the interpretation of fibrin-binding experiments. Blood. 69:769-772.

16. Lijnen, H. R., B. Van Hoef, and D. Collen. 1987. Activation with plasmin of two-chain urokinase-type plasminogen activator derived from single-chain urokinase-type plasminogen activator by treatment with thrombin. Eur. J. Biochem. 169:359-364.

17. Esmon, C. T., N. L. Esmon, and K. W. Harris. 1982. Complex formation between thrombin and thrombomodulin inhibits both thrombin-catalyzed fibrin formation and factor V activation. $J$. Biol. Chem. 257:7944-7947.

18. Owen, W. G., and C. T. Esmon. 1981. Functional properties of an endothelial cell cofactor for thrombin-catalyzed activation of protein C. J. Biol. Chem. 256:5532-5535.

19. Esmon, C. T., and N. L. Esmon. 1984. Protein C activation. Semin. Thromb. Haemostasis. 10:122-130.

20. Freyssinet, J.-M., and J.-P. Cazenave. 1988. Thrombomodulin. In Protein C and Related Proteins. Biochemical and Clinical Aspects. R. M. Bertina, editor. Churchill Livingstone, Edinburgh/London/Melbourne/New York. 91-105.

21. Esmon, C. T. 1989. The roles of protein $C$ and thrombomodulin in the regulation of blood coagulation. J. Biol. Chem. 264:4743-4746.

22. Dittman, W. A., and P. W. Majerus. 1990. Structure and function of thrombomodulin. A natural anticoagulant. Blood. 75:329-336.

23. Badylak, S. F., S. Voytik, R. E. Klabunde, J. Henkin, and M. Leski. 1988. Bolus dose response characteristics of single chain urokinase plasminogen activator and tissue plasminogen activator in a dog model of arterial thrombosis. Thromb. Res. 52:295-312.

24. Kekwick, R. A. 1940. The serum proteins in multiple myelomatosis. Biochem. J. 34:1248-1254.

25. Laemmli, U. K. 1970. Cleavage of structural proteins during the assembly of the head of bacteriophage T4. Nature (Lond.). 227:680-685.

26. Morrissey, J. H. 1981. Silverstain for proteins in polyacrylamide gels: a modified procedure with enhanced uniform sensitivity. Anal. Biochem. 177:307310

27. Esmon, C. T. 1986. Regulation of protein C activation by components of the endothelial cell surface. In Vascular Endothelium in Hemostasis and Thrombosis. M. A. Gimbrone, Jr., editor. Churchill Livingstone, Edinburg/London/ Melbourne/New York. 99-119.

28. Galvin, J. B., S. Kurosawa, K. Moore, C. T. Esmon, and N. L. Esmon. 1987. Reconstitution of rabbit thrombomodulin into phospholipid vesicles. $J$. Biol. Chem. 262:2199-2205.

29. Haley, P. E., M. F. Doyle, and K. G. Mann. 1989. The activation of bovine protein C by factor Xa. J. Biol. Chem. 264:16303-16310.

30. Lijnen, H. R., B. Van Hoef, and D. Collen. 1986. Comparative kinetic analysis of the activation of human plasminogen by natural and recombinant single-chain urokinase-type plasminogen activator. Biochim. Biophys. Acta. 884:402-408.

31. Scully, M. F., V. Ellis, Y. Watahiki, and V. V. Kakkar. 1989. Activation of pro-urokinase by plasmin: non-michaelian kinetics indicates a mechanism of negative cooperativity. Arch. Biochem. Biophys. 268:438-446.

32. Johnson, A. E., N. L. Esmon, T. M. Laue, and C. T. Esmon. 1983. Structural changes required for activation of protein $\mathrm{C}$ are induced by $\mathrm{Ca}^{2+}$ binding to a high affinity site that does not contain $\gamma$-carboxyglutamic acid. J. Biol. Chem. 258:5554-5560.

33. Imada, S., H. Yamaguchi, M. Nagumo, S. Katayanagi, H. Iwasaki, and M. Imada. 1990. Identification of fetomodulin, a surface marker protein of fetal development, as thrombomodulin by gene cloning and functional assays. Dev. Biol. 140:113-122.

34. Eisenberg, P. R., and J. P. Miletich. 1989. Induction of marked thrombin activity by pharmacologic concentrations of plasminogen activators in nonanticoagulated whole blood. Thromb. Res. 55:635-643.

35. Fitzgerald, D. J., and G. A. Fitzgerald. 1989. Role of thrombin and thromboxane $\mathrm{A}_{2}$ in reocclusion following coronary thrombolysis with tissue-type plasminogen activator. Proc. Natl. Acad. Sci. USA. 86:7585-7589. 